\title{
ANALISIS HAMBATAN PERDAGANGAN INTERNASIONAL EKSPOR UDANG INDONESIA
}

\author{
Lia Kamelia Aisya, Sonny Koeshendrajana dan Tjahjo Tri Hartono")
}

\begin{abstract}
ABSTRAK
Kajian analisis hambatan perdagangan internasional ekspor udang Indonesia dilakukan pada bulan Juni sampai dengan bulan September 2004. Penelitian ini bertujuan mengidentifikasi faktor yang menghambat dalam peningkatan kinerja ekspor Indonesia dengan menggunakan metode analisis deskriptif-tabulatif. Hasil analisis menunjukkan bahwa selain hambatan tarif yang tinggi, ekspor udang Indonesia juga menghadapi berbagai hambatan non tarif yang berhubungan dengan standar konservasi internasional yang menambah biaya sehingga menurunkan keunggulan kompetitif Indonesia. Standarisasi hanya akan memberikan efek marjinal pada tingkat harga bagi Indonesia sendiri maupun negara tujuan ekspornya dan menyebabkan "disadvantage price" bagi ekspor komoditas udang Indonesia. Hasil analisis juga menunjukkan bahwa sistem klasifikasi produk Harmonised System yang digunakan untuk mengidentifikasi produk dan tarif yang dikenakan tidak dapat menganalisis trend saat ini, karena system ini hanya merubah substansinya setiap empat tahun sekali. Implikasi kebijakan yang dapat dilakukan oleh pemerintah Indonesia untuk memenangkan persaingan global dan meningkatkan ekspor perikanan yaitu: (1) super efficient, (2) real quality, dan (3) mega marketing.
\end{abstract}

\section{ABSTRACT: International trade barrier analysis for Indonesian shrimp export. By: Lia Kamelia Aisya, Sonny Koeshendrajana and Tjahjo Tri Hartono}

International trade barrier analysis for Indonesian shrimp export was conducted on June until September 2004. Objective of the research was focused on identifying the resistance factors increasing Indonesian Shrimp export. A descriptive-tabulative analysis was used in the study. The results showed, besides high tariff barrier, Indonesia also face various non tariff barrier related to international conservation standard which add expense so that decreased Indonesian competitiveness. Standardization will only give marjinal effect at exporter and importer price rate and cause " price disadvantage' to Indonesia shrimp export. The results also indicated Harmonised System for product classification used to identify type of product and its tariff imposed could not analyse the current-trend due to substational changes of the system every four year. Policy implication for Indonesian government to lead global competition and increase fishery export can be improved through: (1) super efficient production system, (2) real quality of the product, and (3) mega-marketting.

KEYWORDS: trade barrier, international trade, shrimp

\section{PENDAHULUAN}

Sampai saat ini komoditas udang masih merupakan penyumbang terbesar devisa yang berasal dari komoditas perikanan. Data statistik menunjukkan bahwa komoditas udang memberikan kontribusi sebesar $60 \%$ dari total nilai ekspor hasil perikanan (DKP, 2003).

Globalisasi perekonomian yang terjadi saat ini perlu diantisipasi oleh pemerintah dengan membuat berbagai kebijakan sektor perikanan. Kebijakan tersebut haruslah bersifat responsif dan antisipatif menyangkut peluang berupa peningkatan keuntungan yang diperoleh dari perdagangan produk-produk perikanan dengan negara-negara lain serta disisi lain ancaman yang ditimbulkan oleh fenomena globalisasi perekonomian tersebut. Bagi negara yang siap dengan era globalisasi, maka semua akses pasar akan menjadi peluang besar.

Hambatan perdagangan internasional yang dewasa ini dihadapi, baik hambatan tarif maupun nontarif, perlu ditangani secara serius. Di masa mendatang diperkirakan hambatan-hambatan non-tarif yang dikenakan oleh negara-negara maju akan semakin banyak, yang bertujuan salah satunya untuk mencoba melindungi industri dalam negerinya. Selain hambatan-hambatan eksternal, upaya meningkatkan ekspor udang Indonesia juga perlu dibarengi dengan penanganan secara serius terhadap berbagai hambatan internal. Melihat peluang pasar yang masih

, Peneliti pada Balai Besar Riset Sosial Ekonomi Kelautan dan Perikanan 
terbuka, seharusnya hambatan yang muncul baik dari dalam negeri maupun luar negeri, (sebagai negara tujuan ekspor), harus segera diidentifikasi dan ditangani sehingga investor di dalam negeri tertarik terhadap industri udang.

Penelitian ini bertujuan mengidentifikasi faktorfaktor yang menghambat peningkatan kinerja ekspor perikanan Indonesia dengan tujuan yang lebih spesifik yaitu menginventarisasi dan menggolongkan berbagai jenis hambatan tarif dan non-tarif produk perikanan Indonesia khususnya pada komoditas udang, baik dari sisi kebijakan pemerintah Indonesia sendiri maupun dari sisi kebijakan pemerintah negara tujuan ekspor.

\section{METODE}

\section{Kerangka Analisis Data}

Kajian Hambatan Perdagangan Internasional yang dimaksudkan dalam penelitian ini adalah menginventarisasi dan menggolongkan berbagai jenis hambatan tarif dan non-tarif pada komoditas udang, baik hambatan yang berasal dari kebijakan dalam negeri ataupun kebijakan negara tujuan ekspor udang nasional. Analisis hambatan tarif dilakukan dengan melihat tingkat proteksi dan retriksi terhadap komoditas udang Indonesia. Instrumen dari kebijakan tarif adalah kebijakan harga terhadap faktor produksi dan hasil produksi perikanan. Sementara itu, kebijakan non-tarif terkait dengan kebijakan untuk melindungi industri perikanan, terutama yang terkait dengan keamanan pangan (registrasi halal, kandungan bahan kimia, dan perizinan serta aspek lain yang tidak ada kaitannya dengan tarif).

Pada Gambar 1(a) menunjukkan adanya hambatan perdagangan pada barang impor sebesar Pd-PW sehingga menaikkan harga di dalam negeri baik untuk produsen maupun konsumen. Output domestik meningkat dari Q1 ke Q2, sebaliknya konsumsi turun dari Q3 ke Q4. Dengan demikian impor turun dari Q3-Q1 menjadi Q4-Q2. Terdapat transfer penerimaan dari konsumen sebesar PdABPw yaitu kepada produsen sebesar PdEFPw dan kepada pemerintah sebesar FEAB. Efisiensi ekonomi yang hilang dari konsumen adalah perbedaan antara opportunity cost konsumen dalam merubah konsumsi sebesar Q4BCQ3 dengan kemampuan membayar pada tingkat yang sama Q4ACQ3. Sehingga efisiensi ekonomi yang hilang pada konsumen sebesar $A B C$ dan pada produsen sebesar EFG. Untuk gambar 1(b) adalah kebalikan dari Gambar 1(a).

Seluruh kebijakan perdagangan internasional tersebut perlu dikaji dengan baik untuk melindungi Ekspor udang Indonesia, karena di masa mendatang diperkirakan hambatan-hambatan yang dikenakan oleh negara-negara maju akan semakin besar. Analisis deskriptif-tabulatif digunakan dalam kajian ini.

\section{Data dan Sumber Data}

Data primer dan sekunder digunakan dalam penelitian ini. Data primer merupakan data hasil diskusi dan wawancara dengan para stakeholders

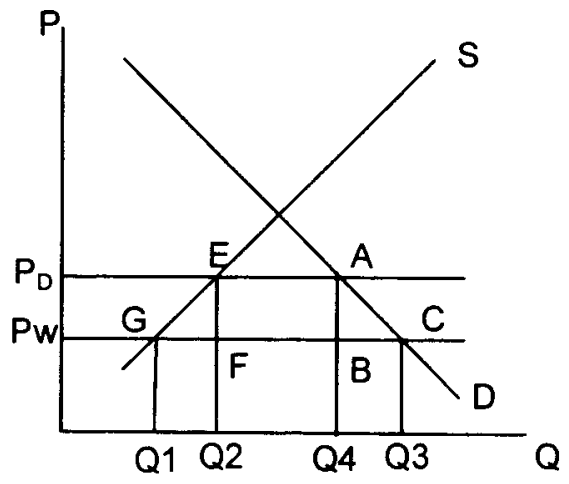

(a) Komoditas impor/lmported commodities

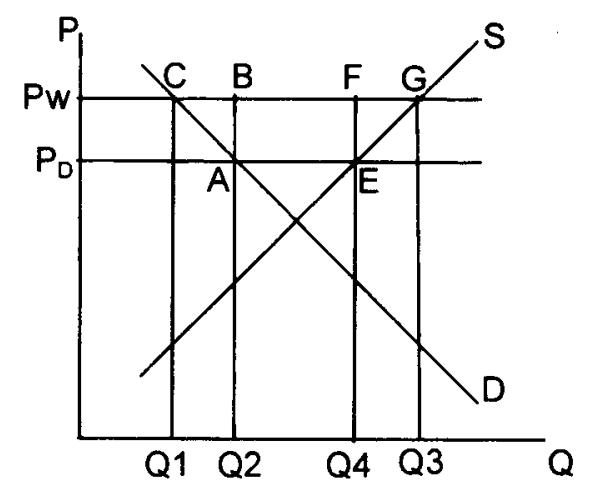

(b) Komoditas ekspor/Exported commodities

Sumber/Source: Monke \& Pearson (1995)

Gambar 1. Hambatan perdagangan untuk komoditas impor dan ekspor.

Figure 1. Trade barrier for import and export commodities. 
seperti pejabat dinas kelautan dan perikanan lokasi riset mengenai peraturan-peraturan daerah tentang perijinan dan persyaratan ekspor udang serta wawancara dengan eksportir mengenai hambatanhambatan internal diluar ketentuan pemerintah. Data sekunder merupakan data dalam bentuk laporan, dokumen serta diperoleh dari beberapa terbitan, yaitu; (1) Statistik Ekonomi dan Keuangan Indonesiapublikasi Bank Indonesia; (2) Statistik Finansial Internasional-publikasi IMF; (3) Data statistik-publikasi DEPPERINDAG; (4) Indikator Ekonomi dalam berbagai tahun publikasi BPS atau publikasi lainnya yang terkait dengan kebutuhan penelitian mengenai berbagai jenis tarif yang dikenakan terhadap ekspor udang Indonesia. Sumber data sekunder adalah instansi-instansi terkait seperti badan instansi teknis lingkup Departemen Kelautan dan Perikanan (Ditjen Perikanan Budidaya), Badan Pusat Statistik, Departemen Perindustrian dan Perdagangan.

\section{Lokasi dan Waktu Penelitian}

Kajian analisis hambatan perdagangan internasional ekspor udang Indonesia dilakukan pada skala nasional, tetapi contoh kasus serta data pendukung difokuskan pada dua lokasi penelitian yaitu Propinsi Sulawesi Selatan dan Propinsi Jawa Timur yang merupakan sentra produksi udang windu yang diproduksi dalam tambak. Pengumpulan data dilaksanakan pada bulan Juni sampai dengan bulan September 2004.

\section{HASIL DAN BAHASAN}

Globalisasi ekonomi yang telah bergulir membuat kebijakan pemerintah dalam bidang perdagangan internasional juga dibatasi oleh ketentuan-ketentuan internasional, baik secara multilateral seperti WTO maupun regional seperti AFTA. Oleh sebab itu perlindungan industri di dalam negeri melalui hambatan perdagangan non tarif dan pemberian subsidi sudah harus mulai dihindari. Begitu pula isuisu penting, seperti Ecolabelling, Perburuhan dan HAM juga perlu mendapatkan perhatian serius. Menurut Rokhman (2003), dengan diterbitkannya Undang-Undang No.7 Tahun 1994 tanggal 2 Nopember 1994 tentang pengesahan (ratifikasi) "Agreement Establising the World Trade Organization", Indonesia secara resmi telah menjadi anggota WTO dan semua persetujuan yang ada didalamnya telah sah menjadi bagian dari legislasi nasional. Menjadi anggota WTO bukan hanya menciptakan peluang (opportunity), tetapi juga ancaman (threat). Bagi negara yang siap dengan globalisasi, maka semua hasil perundingan di banding akses pasar akan menjadi peluang (opportunity) besar. Negara-negara maju telah menurunkan tarif untuk industri dari ratarata $6,3 \%$ menjadi $3,8 \%$ (penurunan sebesar $40 \%$ ). Hal inilah yang menjadi peluang besar terhadap ekspor negara berkembang termasuk Indonesia.

Negara-negara maju melihat WTO sebagai jalan untuk mengejar kesempatan untuk perluasan ekspor, dilain pihak negara-negara berkembang tidak mampu bila tidak disertakan dalam tingkat tarif yang paling rendah yang memungkinkan (status most favoured nation). WTO mempertahankan konsensus struktur dari GATT (tidak ada pengambilan suara, pengambilan keputusan lewat persetujuan yang didalangi oleh kekuatan besar), tetapi memiliki persyaratan keanggotaan baru yang lebih ketat, termasuk pemenuhan TRIPS, yang berarti memiliki peraturan hukum yang mencukupi untuk paten dan hak cipta. WTO dibuat pada tahun 1995, sebagai hasil dari dan sesuai keputusan putaran akhir pembicaraan GATT tahun 1994. Menurut Ghani (2004), General Agreement on Tariff and Trade (GATT)/Perjanjian Umum tentang Tarif dan Perdagangan disusun di tahun 1947 untuk memastikan arus perdagangan pada masa sesudah perang. GATT merupakan suatu reaksi atas proteksi pada tahun 1930-an dan kelompok tersebut menginginkan pencegahan meluasnya pengangguran, proteksi, tarif tinggi dan pengurangan perdagangan tahun 1930-an.

Tujuan utama dibentuknya GATTMTO adalah: (1) Liberalisasi perdagangan untuk meningkatkan volume perdagangan dunia sehingga produksi meningkat; (2) Memperjuangkan penurunan dan bahkan penghapusan hambatan-hambatan perdagangan baik dalam bentuk hambatan tarif bea masuk (tariff barrier) maupun hambatan lainnya (non tariff barrier); (3) Mengatur perdagangan jasa yang mencakup tentang Intellectual Property Rights dan investasi. Dengan meningkatnya produksi akan terjadi peningkatan investasi yang sekaligus akan menciptakan lapangan kerja dan pada gilirannya akan meningkatkan pendapatan masyarakat.

AFTA merupakan suatu bentuk kerjasama perdagangan regional dimana para anggotanya terjadi perdagangan secara bebas, namun tetap mempertahankan tarif masing-masing terhadap negara bukan anggota. Melalui AFTA ini diharapkan tercipta perdagangan bebas di kawasan ASEAN dengan menurunkan tarif antar negara anggota dan mengurangi hambatan non-tarif yang pada akhimya meningkatkan daya saing ASEAN di pasaran dunia. Mekanismenya disepakati melalui CEPT (Common Effective Preferential Tariffs) yaitu skema tarif yang disetujui semua negara anggota ASEAN (Ruru, 1996).

Ada 2 faktor yang menjadi alasan mengapa kehadiran AFTA terasa penting, yaitu: (1) CEPT yang 
menjadi inti AFTA seirama deıgan Putaran Uruguay, sehingga melalui CEPT ini diharapkan dilakukan persiapan-persiapan yang lebih matang dalam melaksanakan kebijakan pengurangan atau penghapusan tarif atau non tarif sebelum diberlakukannya sistem perdagangan multilateral GATTMTO, (2) Melalui AFTA diharapkan memberi manfaat terhadap ekonomi intra ASEAN, yaitu mendorong peningkatan efisiensi sehingga memperkuat posisi ASEAN atas tekanan perdagangan internasional. Bagi Indonesia, pembentukan AFTA setidaknya memperbesar volume perdagangan dan investasi intra ASEAN, serta memperbesar bargaining position dalam menyelesaikan persoalan dengan suatu negara seperti Amerika, Eropa, NAFTA, dan lainnya. Disamping itu tentunya secara tidak langsung menekan industri Indonesia agar menjadi lebih efisien.

Tabel 1. Hambatan internal untuk komoditas udang

Table 1. Internal barrier for shrimps commodities

\section{Hambatan-Hambatan Non-Tarif}

Hambatan Non-Tarif terdiri dari hambatan-hambatan internal dan eksternal. Hambatan internal merupakan hambatan yang dirasakan oleh para eksportir berupa persyaratan dari pemerintah Indonesia yang dianggap terlalu berat atau hambatan yang secara murni berasal dari koridor bisnis pada umumnya. Hambatan eksternal secara umum berpijak pada ketentuan-ketentuan yang berasal dari hakikat yang ada di konsep HACCP (Hazard Analysis Critical Control Point), yaitu keamanan makanan, kemunduran mutu dan penipuan secara ekonomi.

\section{Hambatan-hambatan internal}

Persyaratan yang harus dipenuhi dan berasal dari pemerintah pada dasarnya adalah ketentuan-ketentuan

\begin{tabular}{|c|c|}
\hline $\begin{array}{l}\text { Hambatan non-tarifl } \\
\text { Non-tariff barrier }\end{array}$ & $\begin{array}{l}\text { Hambatan internall } \\
\text { Internal barrier }\end{array}$ \\
\hline \multirow[t]{6}{*}{$\begin{array}{l}\text { Jawa Timur' } \\
\text { East Java }\end{array}$} & $\begin{array}{l}1 \text { Setiap eksportir harus sebagai produsen/ } \\
\text { Exporter is producer }\end{array}$ \\
\hline & 2 ljin SPI/SPI licence \\
\hline & $\begin{array}{l}3 \text { Sertifikat kelayakan pengolahan (SKP)/ } \\
\text { Processing feasibility sertificate }\end{array}$ \\
\hline & $\begin{array}{l}4 \text { HACCP tervalidasi/ } \\
\text { Validated HACCP }\end{array}$ \\
\hline & $\begin{array}{l}5 \text { Persyaratan mutu/ } \\
\text { Quality condition }\end{array}$ \\
\hline & $\begin{array}{l}6 \text { Waktu pengujian/ } \\
\text { Testing period }\end{array}$ \\
\hline \multirow[t]{6}{*}{$\begin{array}{l}\text { Sulawesi Selatan/ } \\
\text { South Sulawesi }\end{array}$} & $\begin{array}{l}1 \text { Ketersediaan bahan bakul } \\
\text { Raw material stock }\end{array}$ \\
\hline & $\begin{array}{l}2 \text { Patokan harga dari supplier/ } \\
\text { Supplier pricing index }\end{array}$ \\
\hline & $\begin{array}{l}3 \text { Penanganan awal bahan baku/ } \\
\text { Raw material handling }\end{array}$ \\
\hline & $\begin{array}{l}4 \text { Kualitas dan kuantitas tenaga quality } \\
\text { control/Quality and quantity of human resources }\end{array}$ \\
\hline & $\begin{array}{l}5 \text { Asosiasi UPI/ } \\
\text { UPI association }\end{array}$ \\
\hline & $\begin{array}{l}6 \text { Spekulasi mutu/ } \\
\text { Quality speculation }\end{array}$ \\
\hline
\end{tabular}

Sumber data: data primer, 2004/Source: primary data, 2004 
Tabel 2. Hambatan eksternal untuk komoditas udang

Table 2. External barriers for shrimps commodities

\begin{tabular}{|c|c|}
\hline $\begin{array}{l}\text { Hambatan non-tarifl } \\
\text { Non-tariff barrier }\end{array}$ & $\begin{array}{l}\text { Hambatan ekste rnal/ } \\
\text { External barrier }\end{array}$ \\
\hline \multirow{3}{*}{$\begin{array}{l}\text { Uni Eropal } \\
\text { Europe Union }\end{array}$} & 1 Kondisi kesehatan/Health condition \\
\hline & $\begin{array}{l}2 \text { Peraturan syarat hygiene minimum/ } \\
\text { Hygiene minimum condition }\end{array}$ \\
\hline & $\begin{array}{l}3 \text { Pengaturan maksimal kontaminasi-kontaminasi } \\
\text { makanan/Contaminan food maximum condition }\end{array}$ \\
\hline \multirow[t]{4}{*}{$\begin{array}{c}\text { Amerika Serikat/ } \\
\text { United State of America }\end{array}$} & $\begin{array}{l}1 \text { Eksportir harus teregistrasi di FDA/ } \\
\text { FDA registeration }\end{array}$ \\
\hline & $\begin{array}{l}2 \text { Persyaratan-persyaratan teknis yang dibuat } \\
\text { FAOIFAO technical condition }\end{array}$ \\
\hline & $\begin{array}{l}3 \text { Sesuai persyaratan terhadap penggunaan } \\
\text { TED/Turtle excluder devices condition }\end{array}$ \\
\hline & 4 ljin tinggal di Amerika/Green ticket \\
\hline \multirow[t]{3}{*}{$\begin{array}{l}\text { Jepang/ } \\
\text { Japan }\end{array}$} & $\begin{array}{l}1 \text { Persyaratan sanitasi dan karantinal } \\
\text { Food sanitation law dan quarantine }\end{array}$ \\
\hline & $\begin{array}{l}2 \text { Persyaratan standar kualitas dan pelabelan } \\
\text { produk/JAS standard system in quality and } \\
\text { labelling }\end{array}$ \\
\hline & 3 Persyaratan Washington/Washington law \\
\hline Australia & $\begin{array}{l}1 \text { Persyaratan karantina Australia/Australian } \\
\text { quarantine inspection senvice/AQ/S }\end{array}$ \\
\hline
\end{tabular}

Sumber data: data primer, 2004/Source: primary data, 2004

yang secara prinsip adalah pemenuhan dari persyaratan dalam rangkaian tata cara ekspor yang sebagian besar hasil kesepakatan dengan negara pembeli. Persyaratan pembeli (buyer) biasanya bersifat ringan, karena pembeli cenderung berpijak pada kesepakatan harga. Negara pembeli mempunyai misi yang berbeda dengan pembeli, yaitu kewajiban melindungi warga negaranya terhadap hal-hal yang membahayakan.

Berdasarkan data dari dinas Kelautan dan Perikanan Jawa Timur, beberapa persyaratan yang merupakan hambatan internal dan harus dipenuhi eksportir udang Indonesia, antara lain: (1) Setiap eksportir harus sebagai produsen, artinya eksportir harus memiliki unit pengolahan ikan (UPI); (2) UPI harus mempunyai ijin sebagai unit yang berkegiatan pengolahan (ijin SPI); (3) UPI harus memenuhi persyaratan kelayakan dasar (prerequisite) sebagai unit pengolahan ikan. Hal ini dibuktikan dengan kepemilikan sertifikat kelayakan pengolahan (SKP) yang dikeluarkan oleh pihak berwenang yaitu
Direktorat Jenderal Perikanan Tangkap melalui prosedur standar; (4) Eksportir yang ekspor ke Uni Eropa, harus menerapkan HACCP (tervalidasi) dan mempunyai nomor persetujuan dari komisi Eropa. Mekanismenya adalah setelah lislus SKP dan validasi HACCP selanjutnya diusulkan ke UE oleh Competent Authorithy dan disetujui oleh UE dengan bukti pemberian Approval Number, (5) Eksportir yang ekspor ke Amerika Serikat harus menerapkan HACCP; (6) Produk yang diekspor wajib memenuhi persyaratan mutu secara laboratoris melalui pengujian di BLPMHP Jawa Timur dan dikeluarkannya sertifikat kesehatan oleh BLPMHP.

Berdasarkan wawancara dengan beberapa petambak, agen pengumpul dan eksportir dari beberapa lokasi penelitian di Sulawesi Selatan dapat diidentifikasi beberapa hambatan internal diluar ketentuan pemerintah, antara lain: (1) Ketersediaan bahan baku yang kadang-kadang sulit diprediksi. Berdasarkan hasil wawancara dengan agen pengumpul hal ini disebabkan oleh gagal panen 
gagal penangkapan dan bahwa sebagian hasil tangkapan laut dijual ke kapal asing; (2) Patokan harga dari agen pengumpul belı'm terbakukan. Berdasarkan pengamatan di lokasi penelitian hal ini disebabkan karena agen pengumpul cenderung berjalan sendiri-sendiri; (3) Penanganan awal bahan baku yang kurang baik. Kondisi seperti ini sering dipaksakan untuk diterima sehingga kualitas bahan baku sampai di UPI tidak sesuai persyaratan; (4) kualitas dan kuantitas tenaga Quality Control tidak sebanding dengan produk; (5) arus isu-isu internasional lambat untuk dipahami. Berdasarkan hasil wawancara dengan eksportir dapat diketahui bahwa masih banyak UPI yang belum bergabung dengan asosiasi yang ada; (6) Keberanian spekulasi mutu. Berdasarkan pengamatan hal ini disebabkan karena kondisi atau kurangnya kesadaran secara nasional.

\section{Hambatan-hambatan eksternal}

Hal yang perlu diperhatikan adalah dalam era globalisasi dan liberalisasi perdagangan, dimana pasar domestik menjadi bagian dari pasar internasional, persaingan akan semakin ketat, dan unit usaha yang dapat bertahan, untung, tumbuh dan berkembang adalah unit usaha yang efisien, dan berdaya saing. Oleh sebab itu, membangun dan meningkatkan keunggulan daya saing kelautan dan perikanan nasional sangat krusial mulai saat ini menuju masa depan.

Dalam meningkatkan daya saing perlu diperhatikan: Pertama, kemampuan menghasilkan suatu komoditi yang lebih murah dari pesaing merupakan syarat perlu untuk menjamin keunggulan daya saing di pasar internasional. Kedua, kemampuan untuk menyediakan produk yang sesuai dengan preferensi konsumen yang berkembang.

Institusialisasi preferensi konsumen tampak dari upaya setiap negara untuk menyusun dan melegalisasi standarisasi dan sertifikasi mutu pangan. Bahkan secara internasional, preferensi konsumen yang demikian telah memperoleh legalisasi dalam aturan WHO yaitu aspek sanitary dan phylosanitary (SPS). Komoditi hasil-hasil perikanan yang tidak memenuhi atribut tersebut akan sulit menembus pasar internasional, bahkan mengalami penolakan dari konsumen.

Hambatan eksternal secara umum berpijak pada ketentuan-ketentuan yang berasal dari hakikat yang ada di konsep HACCP (Hazard Analysis Critical Control Point), yaitu keamanan makanan, kemunduran mutu dan penipuan secara ekonomi. Hasil penelitian mengenai bahaya-bahaya yang terkandung dari hasil perikanan, baik yang bersifat flora normal maupun kesalahan penanganan, menjadi dasar dibuatnya aturan-aturan secara regional maupun internasional. Regional dalam hal ini pemerintah Indonesia membuat Standar Nasional Indonesia (SNI) melalui kajian dan adopsi dari standar Internasional. Begitu juga Kelompok Negara Uni Eropa membuat ketentuan dengan istilah $C D$ (Council Derective).

\section{Hambatan Non-tarif Pasar Uni Eropa}

Persyaratan ekspor ke Uni Eropa cukup ketat. Persetujuan (approval) izin ekspor diberikan oleh Komisi Eropa kepada para eksportir berdasarkan kepada approved packers artinya hanya diberikan kepada perusahaan eksportir yang sudah dianggap qualified-fulfiling the equivalence conditions for the production and plecing on the market dan bukan diberikan kepada semua perusahaan di suatu negara. Jumlah unit pengolah/eksportir produk perikanan Indonesia yang telah mempunyai approval number adalah 261 unit. Bertindak sebagai competent authority di Indonesia untuk mengusulkan daftar perusahaan yang telah memenuhi syarat untuk mengekspor hasil perikanan ke Uni Eropa adalah Direktorat Jenderal Perikanan Tangkap, Departemen Kelautan dan Perikanan. Selain itu, untuk mengawasi standar sanitasi dan mutu produk perikanan impor, Uni Eropa menerapkan sistem pengujian Laboratotium secara acak (random sampling) yang dikenal dengan Rapid Alert System (RAS) di setiap pelabuhan masuk.

Hambatan teknis adalah suatu persyaratan teknis atau persyaratan mutu yang harus dipenuhi oleh eksportir terhadap produk-produk yang dihasilkan. Ketentuan-ketentuan dari kelompok Negara Uni Eropa (UE), yang dapat diidentifikasikan sebagai hambatan secara teknis (Technical barrier) adalah sebagai berikut: (1) kondisi kesehatan dalam produksi dan penempatan di pasarpasar produk perikanan; (2) peraturan syarat hygiene minimum yang harus diterangkan pada produkproduk perikanan tangkap di tempat-tempat pelabuhan kapal ikan; (3) pengaturan maksimal kontaminasi-kontaminasi makanan.

Peraturan UE yang diterapkan untuk produk udang beku sebagian besar sama dengan peraturan yang diterapkan untuk produk perikanan lainnya. Karena pada prinsipnya peraturan-peraturan yang diterapkan UE untuk produk udang khususnya standar kesehatan, keselamatan konsumen dan perlindungan bagi kelestarian lingkungan juga diterapkan untuk produk perikanan. Peraturanperaturan yang diterapkan adalah: (1) Council Decla- 
ration of 30 May 1980 on the Common Fisheries Policy: (2) Council Directive 92/59/EEC of 29 June 1992 on General Product Safety (Rapid Alert System for Foodstuffs); (3) Commission Decision No. 2001/705/EC of 27 September 2001 concerning certain protective measures with regard to certain fishery and aqua-culture products intended for human consumption and originating in Indonesia (notified under document number C(2001) 2935); (4) Council Regulation (EC) No 2578/2000 of 17 November 2000 amending Regulation (EC) No 2406/ 96 laying down common marketing standards for certain fishery products; (5) Council Regulation (EC) No 1298/2000 of 8 June 2000 amending for the fifth time Regulation (EC) No 850/98 for the conservation of fishery resources through techni$\mathrm{cal}$ measures for the protection of juveniles of marine organisms.

Di samping ketentuan-ketentuan di atas, sering terjadi ketentuan yang berasal dari tindak lanjut terjadinya kasus. Misalnya sinyalemen perairan Indonesia yang merupakan fishing ground tuna diduga tercemar logam-logam berat, maka diperintahkan Direktorat Jenderal Perikanan Tangkap untuk menerbitkan surat edaran yang isinya bahwa setiap produk tuna baik segar maupun beku yang diekspor ke UE harus diuji kandungan logam beratnya. Produk udang harus diuji antibiotiknya walaupun RAS terhadap antibiotik sudah dicabut.

\section{Hambatan Non-tarif Pasar Amerika Serikat}

Persyaratan ekspor hasil perikanan ke Amerika Serikat umumnya dikaitkan dengan prinsip good manufacturing practices sebagai pengejawantahan konsep Hazard Analysis Critical Control Point (HACCP). Persyaratan teknis lainnya dikaitkan denga isu lingkungan yaitu CITES, Turtle Excluder Device (TED), Marine Mammal Protection Act (MMPA), ECOLABELLING, DOLPHIN SAFE, dan lain-lain. Selain itu, Amerika Serikat telah lama memberlakukan Automatic Detention.

Pemerintah Amerika Serikat telah membuat ketentuan yang dapat diidentifikasikan sebagai hambatan secara teknis (Technical barrier) sebagai berikut, antara lain : (1) Eksportir harus teregistrasi di FDA, sebagai jaminaan bukan termasuk kelompok industri pangan yang bersifat teroris; (2) Memenuhi persyaratan-persyaratan teknis yang dibuatFAO; (3) Sesuai persyaratan dalam dokumen tambahan yang isinya: surat pernyataan dari pengusaha bahwa udang yang diolah berasal dari budidaya atau dari perairaan Indonesia yang telah diberi verifikasi oleh pemerintah Amerika Serikat terhadap penggunaan Turtle Excluder Devices (TED); (4) Green ticket dari pemerintah USA yang diberikan kepada eksportir yang memenuhi syarat.

Amerika Serikat melarang impor produk perikanan khususnya udang yang tidak mengindahkan standar konservasi Internasional. Hal tersebut tentu saja menambah biaya bagi perikanan Indonesia dan negara tujuan ekspor Indonesia sendiri, sehingga standarisasi tersebut dapat menurunkan keunggulan kompetitif Indonesia. Standarisasi yang juga dikeluarkan beberapa negara OECD tersebut hanya akan memberikan efek marjinal pada tingkat harga bagi Indonesia sendiri maupun negara tujuan ekspornya dan menyebabkan "disadvantage price" bagi ekspor komoditas udang Indonesia.

\section{Hambatan Non-tarif Pasar Jepang}

Untuk memasuki pasar Jepang produk-produk hasil perikanan, dalam keadaan segar, beku maupun olahan dari luar negeri Jepang harus memenuhi syarat yang ditetapkan Food Sanitation Law dan Quarantine, disamping perlu memperhatikan JAS Standard System (quality, labelling) dan Washington law (perlindungan terhadap tanaman dari binatang tertentu). Jepang sebagai negara importir utama hasil perikanan Indonesia juga menerapkan hambatan teknis yang sangat ketat. Analisa kandungan histamin, merkuri dan senyawa-senyawa toksin lainnya serta parasit merupakan persyaratan yang diperlukan bagi ekspor ikan tuna ke Jepang. Disamping itu, semua hasil perikanan yang diekspor ke Jepang harus bebas dari bakteri Vibrio cholera.

Di antara negara-negara OECD, hanya Jepang yang menggunakan hambatan non tarif berupa pembatasan kuota impor. Dengan asumsi bahwa apabila pembatasan kuota impor yang ada diperlonggar, maka akan menyebabkan penurunan harga di pasar Jepang dan peningkatan harga udang di negara Indonesia. Liberalisasi kuota impor akan menyebabkan banyaknya produk perikanan khususnya udang yang masuk ke pasar Jepang.

\section{Hambatan Non-tarif Pasar Australia}

Persyaratan ekspor ke Australia juga cukup ketat. Untuk memasuki pasar Australia harus memenuhi persyaratan Australian Quarantine Inspection Service (AQIS), yaitu suatu ketentuan yang memberikan hak kepada AQIS untuk meneliti sistem jaminan mutu yang diberlakukan oleh perusahaan pengekspor hasil pertanian termasuk perikanan ke Australia.

Pelonggaran hambatan-hambatan non-tarif yang berkaitan dengan masalah lingkungan dan alasan 
Tabel 3. Tarif bea masuk komoditas perikanan ke Indonesia, 2005

Table 3. Indonesian tariff for fisheries commodities, 2005

\begin{tabular}{|c|c|c|c|c|c|}
\hline No & $\begin{array}{l}\text { Sektorl } \\
\text { Sector }\end{array}$ & Tarif max. & Tarif min. & $\begin{array}{c}\text { Tarif rata-ratal } \\
\text { Average }\end{array}$ & ERP \\
\hline 31 & $\begin{array}{l}\text { Ikan laut dan hasil laut } \\
\text { lainnya/Marine fish product }\end{array}$ & 15 & 0 & 5.13 & 5.95 \\
\hline 32 & $\begin{array}{l}\text { Ikan darat dan hasil perairan } \\
\text { darat/Freshwater fish product }\end{array}$ & 15 & 0 & 6.88 & 7.88 \\
\hline 33 & Udang/Shrimp & 5 & 5 & 5 & 6.43 \\
\hline 53 & $\begin{array}{l}\text { Ikan kering dan ikan asin/ } \\
\text { Salted fish product }\end{array}$ & 5 & 5 & 5 & 10.04 \\
\hline 54 & $\begin{array}{l}\text { Ikan olahan dan awetan/ } \\
\text { Processed fish product }\end{array}$ & 5 & 0 & 4.95 & 8.59 \\
\hline
\end{tabular}

Sumber/Source: Tim Tarif DKP, 2005

Keterangan/Remaks: ERP (Effective Rate Protection)

konservasi juga akan menghasilkan dampak yang sama dengan liberalisasi kuota impor, dimana hal tersebut akan meningkatkan harga komoditas udang dengan spesies yang sama di negara eksportirnya (Indonesia) dan justru akan menurunkan harga di negara tujuan utama ekspor udang indonesia. Volume produksi udang Indonesia tercatat rata-rata 53.023 ton per tahun. Sebanyak $85 \%$ atau $45.069,55$ ton dari total volume tersebut diekspor. Negara yang terbanyak mengimpor udang Indonesia adalah Jepang, yakni rata-rata 23.000 ton per tahun. Nilai ekspor udang Indonesia tahun 2000 sebesar US\$101,94 juta. Tahun 2001 hanya mencapai US $\$ 91,484$ juta dan pada tahun 2002 merosot lagi mencapai US $\$ 49,208$ juta. Penurunan itu merupakan dampak dari kebijakan pengetatan impor udang melalui berbagai hambatan non tarif yang dilakukan Uni Eropa dan Amerika Serikat seperti kebijakan agar udang yang diimpor sama sekali tidak mengandung (0\%) antibiotik chloramphenicol, nitrofuransi dan furazidon atau kebijakan zero tolerance.

\section{Hambatan-Hambatan Tarif}

Pemerintah telah melakukan berbagai kebijakan untuk mengurangi hambatan ekspor. Tindakan mengurangi tarif memberi dorongan bagi kegiatan perdagangan ekspor maupun impor. Penurunan tarif terutama ditujukan kepada bahan penolong dan bahan baku yang mendukung industri berorientasi ekspor. Berikut ini tarif bea masuk komoditas perikanan ke Indonesia yang diinventarisasi berdasarkan data dari Departemen Kelautan Perikanan.

Untuk menembus pasar global, khususnya untuk memasuki pasar negara-negara maju, selain harus mensiasati berbagai hambatan non tarif, sektor perikanan Indonesia juga harus menghadapi hambatan tarif yang cukup tinggi. Penurunan tarif yang diharapkan bagi ekspor perikanan Indonesia khususnya ekspor udang dari dampak yang mungkin terjadi dari adanya Muttilateral Trade Agreements dan World Trade Organisation (WTO) dalam perdagangan internasional produk-produk perikanan hanya menghasilkan penurunan sebesar $26 \%$ (dari sekitar $6,1 \%$ menjadi $4,5 \%$ ), sementara tarif bagi produk-produk industri yang diimpor dari negaranegara maju harus diturunkan sebesar $40 \%$.

Total hasil negara OECD dari pengenaan tarif pada produk perikanan sebesar US\$ 1 milyar per tahun. Tarif yang dikenakan sesungguhnya lebih rendah dari batas perjanjian tarif MFN. Pengenaan tarif berbeda-beda pada beberapa negara OECD. Untuk produk perikanan mentah yang masih belum diproses lebih lanjut tarif yang dikenakan lebih rendah sebesar 2,5\% daripada tarif yang dikenakan untuk produk perikanan yang sudah diproses sebesar $6,3 \%$.

Kurangnya transparansi pada pengenaan tarif ditambah dengan kompleksitasnya peraturan pengenaan tarif pada beberapa negara OECD membuat detail tarif sulit untuk dianalisis, yang mana berdasarkan kesepakatan setiap anggota WTO harus 
Tabel 4. Tarif bea masuk komoditas udang di Uni Eropa, 2004

Table 4. MFN tariff for shrimp commodity at Europe Union, 2004

\begin{tabular}{llc}
\hline HS code & \multicolumn{1}{c}{ Product } & Tariff \\
\hline 03061310 & Of the family pandalidae & $12 \%$ \\
03061330 & Shrimps of the genus crangon by boiling in water & $12 \%$ \\
03061340 & Deepwater rose shrimps (Parapenaeus) & $12 \%$ \\
03061350 & Shrimps of the genus Penaeus & $12 \%$ \\
03061380 & Other & $12 \%$ \\
03062100 & Rock lobster by boiling in water & $12,5 \%$ \\
03062210 & Live lobster & $8 \%$ \\
03062331 & Shrimps of the genus Crangon fresh, chilled, live, & $18 \%$ \\
& dried, salted & \\
16052010 & Shrimps and prawns preserved in immediate packing & $20 \%$ \\
& of $<2 \mathrm{~kg}$ & $20 \%$ \\
16052091 & Shrimps and prawns preserved in immediate packing & \\
& of $>2 \mathrm{~kg}$ & $13,3 \%$ \\
\hline 16053000 & Lobster preserved or prepared & \\
\hline
\end{tabular}

Sumber/Source: APEC Tarif, 2004

Tabel 5. Pajak tambahan untuk produk makanan di Uni Eropa, 2004

Table 5. VAT rates (in \%) for food products at Europe Union, 2004

\begin{tabular}{lcccc}
\hline & Zero rate & Super reduced & Reduced rate & Standard rate \\
\hline Belgia & - & - & 6 & 21 \\
Denmark & - & - & - & 25 \\
Jerman & - & - & 7 & 16 \\
Yunani & - & - & 8 & - \\
Spanyol & - & 4 & 7 & - \\
Perancis & - & - & 5,5 & 19,6 \\
Irlandia & 0 & 4,2 & 12,5 & 21 \\
Itali & - & 4 & 10 & - \\
Luksemburg & - & 3 & - & - \\
Belanda & - & - & 6 & - \\
Austria & - & - & 10 & - \\
Portugal & - & - & $5 / 12$ & 17 \\
Finlandia & - & - & 17 & - \\
Swedia & - & - & 12 & 25 \\
Inggris & 0 & - & - & - \\
\hline SumberSourc: & APE & - & & \\
\hline
\end{tabular}

Sumber/Source: APEC Tarif, 2004 
mematuhi tarif yang diberlakukan. Informasi tarif yang tidak mudah tersedia membuat pelaku perdagangan produk perikanan mendapat ketidak pastian dan resiko yang lebih besar karena tidak mengetahui berapa tarif yang dikenakan pada ekspor produk perikanannya.

Sistem klasifikasi produk Harmonised System digunakan untuk mengidentifikasi produk dan tarif yang dikenakan. Tetapi sistem ini hanya merubah substansinya setiap empat tahun sekali, dimana hal tersebut tidak dapat menganalisis trend saat ini dari perkembangan perikanan di seluruh dunia. Negara-negara yang memiliki karakteristik perikanan yang diklasifikasikan sebagai spesies baru akan mendapat kerugian, karena produk perikanan yang tidak terdaftar dalam daftar tarif akan dimasukkan ke dalam daftar tarif "other" yang biasanya memiliki tingkat tarif yang lebih tinggi. Berikut ini beberapa hambatan tarif baik berupa bea masuk maupun pajak konsumsi di negara Uni Eropa, Amerika Serikat dan Jepang.
Berdasarkan Pasal 7 point 2 dari Skema GSP untuk periode 1 Januari 2002 s/d 31 Desember 2004, produk schrimps prawns merupakan produk yang termasuk dalam daftar produk "sensitif" oleh sebab itu produk tersebut mendapatkan preferensi penurunan tarif $3,5 \%$. Tarif normal MFN sebesar $12 \%$. Namun demikian pada skema yang lama penurunan tarif yang diperoleh lebih besar dari $3.5 \%$. Berdasarkan artikel 7 point 3 beneficiary diperbolehkan untuk menggunakan ketentuan yang lama jika penurunan tarif pada skema GSP sebelumnya lebih tinggi. Oleh sebab itu tarif produk udang beku di UE dengan GSP akan diberlakukan sesuai dengan tarif yang lama yaitu sebesar $4,2 \%$.

Walaupun sejak 1 Januari 1993 UE telah berusaha mengadakan harmonisasi Value Added Tax (pajak yang dikenakan pada tingkat penjualan ke konsumer akhir) negara-negara anggota UE, namun sampai sekarang hal tersebut belum mencapai hasil. Sebagai akibatnya masing-masing negara

Tabel 6. Tarif bea masuk komoditas udang di Amerika Serikat, 2004

Table 6. MFN tariff for shrimp commodity at United State of America, 2004

\begin{tabular}{|c|c|c|}
\hline HS code & Product & Tariff \\
\hline 03061310 & Of the family pandalidae & Free \\
\hline 03061330 & $\begin{array}{l}\text { Shrimps of the genus crangon by boiling in } \\
\text { water }\end{array}$ & Free \\
\hline 03061340 & Deepwater rose shrimps (parapenaeus) & Free \\
\hline 03061350 & Shrimps of the genus penaeus & Free \\
\hline 03061380 & Other & Free \\
\hline 03062100 & Rock lobster by boiling in water & Free \\
\hline 03062210 & Live lobster & Free \\
\hline 03062331 & $\begin{array}{l}\text { Shrimps of the genus crangon fresh, chilled, live, } \\
\text { dried, salted }\end{array}$ & Free \\
\hline 16052010 & $\begin{array}{l}\text { Shrimps and prawns not containing fish meat } \\
\text { preserved in immediate packing of }<2 \mathrm{~kg}\end{array}$ & Free \\
\hline 16052091 & $\begin{array}{l}\text { Shrimps and prawns not containing fish meat } \\
\text { preserved in immediate packing of }>2 \mathrm{~kg}\end{array}$ & Free \\
\hline 16052005 & $\begin{array}{l}\text { Shrimps and prawns product containing fish meat } \\
\text { or prepared meals }\end{array}$ & $5 \%$ \\
\hline 16053005 & $\begin{array}{l}\text { Lobster preserved or prepared containing fish } \\
\text { meat }\end{array}$ & $10 \%$ \\
\hline 16053010 & $\begin{array}{l}\text { Lobster preserved or prepared not containg fish } \\
\text { meat }\end{array}$ & Free \\
\hline
\end{tabular}

Sumber/Source: APEC Tarif, 2004 
Tabel 7. Tarif bea masuk komoditas udang di Jepang, 2004

Table 7. MFN tarif for shrimp commodity at Japan, 2004

\begin{tabular}{|c|c|c|}
\hline HS code & Product & Tariff \\
\hline 03061310 & Of the family pandalidae & Free \\
\hline 03061330 & $\begin{array}{l}\text { Shrimps of the genus crangon by boiling in } \\
\text { water }\end{array}$ & Free \\
\hline 03061340 & Deepwater rose shrimps (parapenaeus) & Free \\
\hline 03061350 & Shrimps of the genus Penaeus & Free \\
\hline 03061380 & Other & Free \\
\hline 03062100 & Rock lobster by boiling in water & Free \\
\hline 03062210 & Live lobster & Free \\
\hline 03062331 & $\begin{array}{l}\text { Shrimps of the genus Crangon fresh, chilled, live, } \\
\text { dried, salted }\end{array}$ & Free \\
\hline 16052010 & $\begin{array}{l}\text { Shrimps and prawns not containing fish meat } \\
\text { preserved in immediate packing of }<2 \mathrm{~kg}\end{array}$ & $4,8-5,3 \%$ \\
\hline 16052091 & $\begin{array}{l}\text { Shrimps and prawns not containing fish meat } \\
\text { preserved in immediate packing of }>2 \mathrm{~kg}\end{array}$ & $4,8-5,3 \%$ \\
\hline 16052005 & $\begin{array}{l}\text { Shrimps and prawns product containing fish meat } \\
\text { or prepared meals }\end{array}$ & $4,8-5,3 \%$ \\
\hline 16052001 & Other & Free \\
\hline 16053005 & $\begin{array}{l}\text { Lobster preserved or prepared containing fish } \\
\text { meat }\end{array}$ & $4,8-5 \%$ \\
\hline 16053010 & $\begin{array}{l}\text { Lobster preserved or prepared not containg fish } \\
\text { meat }\end{array}$ & $4,8-5 \%$ \\
\hline
\end{tabular}

Sumber/Source: APEC Tarif, 2004

anggota memberlakukan VAT yang berbeda untuk produk makanan.

Tarif bea masuk yang dikenakan negara Amerika Serikat pada produk udang yang tidak diolah (beku, direbus, digarami, dikeringkan) adalah $0 \%$ atau free. Untuk produk udang olahan tarif bea masuk yang dikenakan adalah 5\%-10\%, bahkan kadang diterapkan "special rate" yang lebih tinggi yaitu $20 \%$.

Tarif umum yang diterapkan negara Jepang pada komoditas udang olahan adalah sebesar $4,8 \%-6 \%$ sementara tarif dari WTO diwajibkan sebesar 4,8\%-5,3\% \%. "Special Rate" yang diberikan negara Jepang untuk produk olahan sebesar $3,2 \%$, tetapi untuk produk olahan yang termasuk kategori "other" diberikan tarif $0 \%$ atau free. Untuk produk udang non olahan (beku, direbus, digarami, dikeringkan) juga diberikan tarif bea masuk $0 \%$ atau free.

Liberalisasi perdagangan bagi komoditas udang olahan juga akan menurunkan harga sebagai akibat dari banyaknya supplai udang olahan, dimana penurunan harga tersebut akan menekan harga dari produksi domestik spesies udang yang sama. Tarif bea masuk produk udang olahan yang relatif lebih tinggi di berbagai negara pengimpor mengakibatkan eksportir udang Indonesia lebih memilih untuk mengekspor udang yang belum diolah lebih lanjut daripada udang olahan.

Pengurangan atau pengecualian tarif, pembukaan kuota atau pengaturan "preferential" (peluang untuk mendapatkan penurunan tarif bea masuk) akan membuat peningkatan harga di negara pengekspor (Indonesia) komoditas perikanan khususnya udang dan di lain pihak akan menurunkan harga di negara importir (Amerika Serikat, Uni Eropa dan Jepang). Dampak dari adanya liberalisasi perdagangan (penurunan tingkat tarif) pada ekspor komoditas udang Indonesia yang non olahan akan diikuti oleh penurunan harga species udang yang sama di negara pengimpor. Konsekuensinya, kecuali negara pengimpor itu 
Tabel 8. Kebijakan antisipatif pemerintah dalam menghadapi hambatan perdagangan Internasional

Table 8. Government anticipation policy facing the International trade barrier

\begin{tabular}{|c|c|c|}
\hline No & $\begin{array}{c}\text { Hambatan perdagangan/ } \\
\text { Trade barrier }\end{array}$ & $\begin{array}{l}\text { Kebijakan antisipatif pemerintah/ } \\
\text { Government anticipation policy }\end{array}$ \\
\hline 1 & $\begin{array}{l}\text { Residu chloramphenicol/ } \\
\text { Chloramphenicol residu }\end{array}$ & $\begin{array}{l}\text { Penerapan HACCPI } \\
\text { HACCP applied }\end{array}$ \\
\hline 2 & $\begin{array}{l}\text { Embargo udang/ } \\
\text { Shrimp embargo }\end{array}$ & $\begin{array}{l}\text { Kebijakan pemilihan produk/ } \\
\text { Trade leverage }\end{array}$ \\
\hline 3 & $\begin{array}{l}\text { Isu lingkungan dan pelabelan/ } \\
\text { Environment issue and ecolabelling }\end{array}$ & $\begin{array}{l}\text { Pelabelan organik/ } \\
\text { Organic labelling }\end{array}$ \\
\hline 4 & $\begin{array}{l}\text { Penetrasi pasar/ } \\
\text { Market penetration }\end{array}$ & $\begin{array}{l}\text { Perjanjian pengakuan mutu/ } \\
\text { Mutual recognition agreement }\end{array}$ \\
\hline 5 & $\begin{array}{l}\text { Embargo kerang-kerangan/ } \\
\text { Shell embargo }\end{array}$ & $\begin{array}{l}\text { Program sanitasi/ } \\
\text { Sanitation program }\end{array}$ \\
\hline 6 & Tarif bea masuk/MFN tariff & Fasilitas GSP/GSP fasilities \\
\hline 7 & $\begin{array}{l}\text { Sanksi sementara/Temporary } \\
\text { suspension }\end{array}$ & $\begin{array}{l}\text { Program pengendalian residu hormon } \\
\text { dan antibiotik/Antibiotic and hormon } \\
\text { residu controlling program }\end{array}$ \\
\hline
\end{tabular}

Sumber/Source: DKP, 2003

sendiri dapat meningkatkan produksi, maka pendapatan rata-ratanya akan turun disaat konsumen di negara pengimpor mendapatkan keuntungan dari adanya penurunan harga.

\section{Kebijakan Penanganan Pemerintah Terhadap Hambatan Perdagangan Internasional}

Hambatan-hambatan perdagangan internasional yang dihadapi pemerintah seperti banyaknya penahanan terhadap pengapalan udang dari Indonesia, yang terkena residu chloramphenicol, serta adanya embargo udang, kerang-kerangan dan temporary suspension serta berbagai isu lingkungan dan ecolabelling perlu ditangani dengan cepat dan efisien.

Diperlukan langkah-langkah penanganan untuk meningkatkan efisiensi dan daya saing di pasar internasional. Berikut ini adalah kebijakan penanganan terhadap berbagai hambatan perdagangan internasional yang dilakukan oleh pemerintah.

\section{- Penanganan masalah residu chloramphenicol}

Dengan banyaknya penahanan terhadap pengapalan udang dari Indonesia di Uni Eropa akhir- akhir ini, maka diperlukan langkah-langkah penanganan yang cepat dan terpadu termasuk penerapan program HACCP (Hazard Analysis Critical Control Point) secara sistematis mulai dari tingkat perbenihan sampai pengolahan. $\mathrm{Hal}$ ini mengingatkan bahwa udang-udang yang tercemar chloramphenicol tersebut diancam untuk dimusnahkan.

\section{- Penanganan terhadap embargo udang oleh Amerika Serikat}

Untuk memecahkan masalah "embargo" terhadap ekspor udang oleh Amerika Serikat, maka diperlukan konsolidasi antara Departemen Kelautan dan Perikanan dengan departemen-departemen terkait khususnya Depperindag dan Departemen Pertanian. Hal ini mengingat adanya indikasi bahwa masalah tersebut dikaitkan dengan larangan impor paha ayam dari Amerika Serikat oleh pemerintah RI (cq. Departemen Pertanian).

\section{- Penanganan terhadap isu lingkungan dan ocolabelling}

Dengan semakin maraknya penggunaan isu lingkungan dan ecolabelling dalam perdagangan internasional komoditi perikanan, maka diperlukan langkah-langkah penanganan antisipatif, agar 
masalah ini tidak mengganggu kelancaran ekspor hasil perikanan di tahun-tahun mendatang. Di Sidoarjo, Jawa Timur, pelabelan organik untuk udang-udang yang diekspor dilakukan sehingga produk-produk ekspor Indonesia dapat dikatakan sudah mulai ramah lingkungan.

\section{- Mutual recognition agreement (MRA)}

Selain perbaikan dalam sistem produksi, penangkapan, penanganan dan pengolahan produk akhir, upaya untuk mendorong terbentuknya saling pengakuan (mutual recognition agreement) dengan negara-negara mitra dagang luar negeri dirasakan sangat mendesak. Hal ini mengingat bahwa sampai saat ini program MRA untuk ekspor hasil perikanan baru terjalin dengan Uni Eropa, sedang dengan negara-negara mitra dagang lainnya terutama Amerika Serikat, Kanada, dan Australia sampai saat ini masih belum tuntas. Program MRA ini selain akan mendorong kelancaran ekspor produk perikanan ke negara tujuan juga akan membantu dalam penetrasi pasar dan mendapatkan akses pasar.

\section{- Fasilitas GSP}

Mengingat saat ini Indonesia dilanda krisis ekonomi yang berkepanjangan maka diperlukan konsolidasi untuk menjajaki peluang pemberian fasilitas GSP bagi ekspor hasil perikanan terutama dari Jepang dan Uni Eropa. Hal ini mengingat masih tingginya tarif bea masuk impor yang diperlukan oleh kedua negara ini, disamping peluang untuk mendapatkan penurunan tarif bea masuk sangat sulit atau bahkan tidak mungkin.

\section{- Pengembangan program sanitasi kerang- kerangan.}

Penanganan terhadap masalah ini dirasakan sangat mendesak, mengingat potensi pengembangan ekspor kerang-kerangan ke Uni Eropa khususnya dari Jawa Timur dan Sumatera Utara adalah sangat besar. Apalagi mengingat telah adanya komitmen dari pihak Komisi Eropa untuk mengadakan inspeksi ke Indonesia dalam rangka mencari upaya pemecahan terhadap embargo ekspor kerang-kerangan tersebut.

\section{- Pengendalian residu hormon dan antibiotik}

Penyusunan program pengendalian dan monitoring residu hormon dan antibiotik ikan/udang hasil budidaya juga memerlukan penanganan yang mendesak. Hal ini terutama disebabkan karena Indonesia berkewajiban untuk menyampaikan program pengendalian dan monitoring residu hormon dan antibiotik pada budidaya ikan kepada Komisi Eropa agar tidak terkena "temporary suspension".

\section{KESIMPULAN DAN IMPLIKASI KEBIJAKAN}

Dari uraian di atas terlihat bahwa liberalisasi perdagangan mempunyai implikasi yang besar terhadap perdagangan hasil perikanan dunia dan pengembangan usaha perikanan di Indonesia. Namun demikian, pada kenyataannya dalam perdagangan hasil perikanan terlihat adanya kecenderungan negara-negara industri maju untuk menggunakan hambatan non tarif berupa hambatan teknis (technical barrier) maupun aspek sanitasi dan fitosanitasi sebagai hambatan terselubung (disguished restriction) demi kepentingan nasionalnya. Hal ini karena berdasarkan perjanjian GATT-Putaran Uruguay, setiap negara anggota WTO diperbolehkan untuk memberlakukan peraturan mengenai masalah teknis dan aspek sanitasi dan fitosanitasi sepanjang untuk tujuan melindungi keselamatan dan kesehatan manusia, hewan maupun tanaman serta melindungi konsumen dari hal-hal yang merugikan.

Sementara itu, bagi Indonesia dan negara-negara berkembang lainnya diperkirakan akan sedikit atau kurang dapat memanfaatkan peluang-peluang yang ada dari globalisasi ekonomi ini. Bahkan dikhawatirkan bahwa tanpa adanya konsolidasi dan pembenahanpembenahan, kelancaran ekspor hasil perikanan indonesia justru akan terhambat dengan adanya perdagangan bebas. Dilain pihak, Indonesia dapat menjadi dumping ground dari membanjirnya produkproduk perikanan dari luar negeri karena peraturan mengenai masalah teknis dan sanitasi dan fitosanitasi di Indonesia masih lemah serta pangsa pasar dalam negeri yang cukup besar.

Belum optimalnya kinerja ekspor hasil perikanan Indonesia banyak disebabkan oleh berbagai kendala terutama hambatan tarif dan non tarif seperti standar mutu, sanitasi yang semakin ketat serta isu-isu lingkungan. Pemerintah telah melakukan berbagai kebijakan untuk mengurangi hambatan ekspor diantaranya adalah, investor asing diperbolehkan melakukan ekspor langsung tanpa berekanan dengan perusahaan domestik. Pengurangan tarif saja kurang memadai untuk meningkatkan efisiensi perekonomian karena masalah terbesarnya adalah hambatan non tarif berupa pungutan resmi maupun tidak resmi dan bentuk-bentuk lisensi. Penghapusan hambatan non tarif semestinya didahulukan karena dalam proses penahapan ke arah perdagangan bebas, masih dibutuhkan instrumen tarif untuk mengurangi laju impor yang cenderung meningkat pesat, khususnya impor barang konsumsi.

Implikasi kebijakan yang dapat dilakukan oleh pemerintah Indonesia dalam mengembangkan 
usaha perikanan harus men,perhatikan 3 (tiga) persyaratan untuk memenangkan persaingan global, yaitu: (1) super efficient, (2) real quality, dan (3) mega marketing. Super efficient dimaksudkan bahwa proses produksi dan pemasaran produk perikanan harus dilakukan secara efisien, sehingga harga jual produk tersebut bisa lebih rendah dari yang ditawarkan oleh negara kompetitor. Untuk mencapai tingkat efisiensi yang tinggi diperlukan penguasaan teknologi dan manajemen yang memadai pada sisi pelaku usaha, dan penerapan standar pelayanan prima pada sisi pemerintah. Real quality dimaksudkan bahwa produk hasil perikanan harus betul-betul bermutu tinggi. Untuk itu pembinaan dan pengawasan mutu harus ditangani secara lebih serius untuk mendapatkan mutu yang konsisten sesuai permintaan pasar. Sedangkan mega marketing dimaksudkan bahwa kita harus selalu melakukan market intelligence, untuk mempertahankan pasar yang sudah kita kuasai dan meningkatkan akses pasar yang lebih luas.

Strategi di atas dapat diimplementasikan melalui berbagai langkah operasional, antara lain: (a) Menerapkan kaidah-kaidah yang termuat dalam FAOCode of Conduct for Responsible Fisheries dalam pengelolaan sumberdaya ikan; (b) Restrukturisasi industri penangkapan ikan nasional dengan meningkatkan komposisi kapal-kapal besar yang berkemampuan jelajah tinggi, terutama untuk mengeksploitasi sumberdaya ikan di perairan KTI dan ZEEI; (c) Mengembangkan komoditas unggulan yang mempunyai daya saing tinggi; (d) Mengembangkan prasarana perikanan terutama di KTI, seperti Pelabuhan Perikanan/Pangkalan Pendaratan Ikan guna mendukung peningkatan pemanfaatan sumberdaya ikan di kawasan tersebut; (e) Meningkatkan kemampuan penetrasi pasar dan daya saing produk perikanan di pasar internasional melalui: peningkatan mutu produk, diversifikasi produk, diversifikasi pasar, penguasaan informasi pasar, peningkatan kegiatan promosi dan peningkatan akses pasar melalui
Memorandum of Understanding (MOU)/Mutual Recognition Agreement (MRA) dengan negara importir potensial. (f) Mengembangkan usaha perikanan yang berwawasan lingkungan untuk menjaga kelestarian sumberdaya ikan dan lingkungan hidup, serta untuk menangkal issuissu lingkungan yang dituntut negara-negara mitra dagang; (g) Menerapkan Program HACCP secara konsisten pada seluruh tahapan produksi hasil perikanan, untuk memberikan jaminan mutu yang lebih tinggi kepada konsumen baik di dalam maupun di luar negeri.

\section{DAFTAR PUSTAKA}

Anonymous. Download from $h t t p / / w w w$. Apectarif .com. on November 12, 2004

Bank Indonesia, Statistik Ekonomi Keuangan Indonesia, berbagai edisi, Jakarta.

Biro Pusat Statistik, Statistik Ekspor Impor Indonesia, berbagai edisi, Jakarta.

Depperindag. 2003a. Data Statistik Indikator Perekonomian Dalam Negeri, berbagai edisi. Jakarta.

Deperindag. 2003. Data Statistik Ekspor Impor Indonesia, berbagai edisi. Jakarta.

DKP. 2003. Laporan Sidang Global Shrimp. Jakarta

DKP. 2005. Laporan Tim Tarif. Ditjen PK2P. Jakarta

Ghani. 2004. Analisis Ketergantungan Perekonomian dan Daya Saing Ekspor Indonesia. Tesis. Program Pasca Sarjana. Universitas Indonesia.

LPEM. 2003. Pemantapan Ekspor Non Migas ke Negara Non Tradisional. Jakarta.

Monke E.A. and S. Pearson. 1995. The Policy Matrix For Agricultural Development. Cornell University Press. London.

Rokhman, A. 2003. Implikasi globalisasi ekonomi terhadap pengembangan usaha perikanan. Makalah Falsafah Sains. Program Pasca Sarjana. Institut Pertanian Bogor.

Ruru, Bacelius. 1996. Arah kebijakan Badan Usaha Milik Negara: Menghadapi Era Asean Free Trade Area (AFTA) 2003 dan Asia Pasific Economic Coorperation (APEC) 2020. Usahawan 25 (05): 9-6. 